\title{
Differential impacts of coral reef herbivores on algal succession in Kenya
}

\author{
A. T. Humphries ${ }^{1,2, *}$, T. R. McClanahan ${ }^{3}$, C. D. McQuaid ${ }^{1}$ \\ ${ }^{1}$ Coastal Research Group, Department of Zoology and Entomology, Rhodes University, Grahamstown 6140, South Africa \\ ${ }^{2}$ Coral Reef Conservation Project, Wildlife Conservation Society, PO Box 99470, Mombasa 80107, Kenya \\ ${ }^{3}$ Wildlife Conservation Society, Marine Programs, Bronx, New York, NY 10460, USA
}

\begin{abstract}
In shallow-water systems, fisheries management influences herbivory, which mediates ecosystem processes by regulating algal biomass, primary production, and competition between benthic organisms, such as algae and corals. Sea urchins and herbivorous fishes (scrapers, grazers, browsers) are the dominant herbivores in Kenya's fringing coral reef and their grazing influences coral-macroalgal dynamics and dominance. Using experimental substrata and grazer exclusions, we tested the hypothesis that herbivores differentially affect algal composition and succession using 3 levels of fisheries management: fished reefs, community-managed closures $\left(<10 \mathrm{yr}\right.$ old,$\left.<0.5 \mathrm{~km}^{2}\right)$, and government-managed closures $\left(20\right.$ to $40 \mathrm{yr}$ old, 5 to $\left.10 \mathrm{~km}^{2}\right)$. In fished reefs and government closures, herbivores facilitated maintenance of early successional algal species, such as turfs, associated with sea urchins in the former and scraping fishes in the latter. Crustose coralline algae were only abundant in government closures, and video recordings showed that fish grazing was greatest at these sites, most notably for parrotfishes (scrapers). A combination of sea urchins and small grazing and detritivorous fishes was present in community closures, which allowed macroalgae to quickly develop from turf into early then late successional stages. These reefs may represent an intermediate or transitional system of herbivore dominance characterized by macroalgae. Consequently, reefs in heavily fished seascapes initially protected from fishing may require additional management efforts to facilitate the recovery of larger-bodied scraping fishes, including bans on capturing parrotfishes and restricting gear (e.g. spearguns) that target these species.
\end{abstract}

KEY WORDS: Animal-plant interactions - Community-based management $\cdot$ Marine protected area and reserves $\cdot$ Niche replacement $\cdot$ Phase shift $\cdot$ Primary succession $\cdot$ Resilience

Resale or republication not permitted without written consent of the publisher

\section{INTRODUCTION}

In both terrestrial and aquatic systems, herbivory is a key top-down process that mediates the abundance of primary producers and hence overall community composition (Jones 1992, Schmitz et al. 2000, Scheffer et al. 2001, Mumby et al. 2006). On tropical coral reefs, macroalgae compete with corals for space, nutrients, and light, and herbivores may mediate antagonistic interactions between these 2 primary space occupiers (Hay 1997, McCook et al. 2001). A critical factor governing coral reef growth and sustainability is the maintenance of suitable recruitment space for coral larvae, which is often achieved through high herbivore abundance and low abundance of foliose macroalgae (Mumby 2006). However, herbivore communities are increasingly being affected by overfishing, potentially undermining the ability of reefs to resist a phase shift to dominance by macroalgae (Hughes 1994, McClanahan et al. 2011a) and recover from disturbances (Nugues \& Bak 2006, Hughes et al. 2007). Here, transitions to macroalgae generally progress from filamentous turf algae and crustose coralline algae (CCA) to corticated and fleshy macroalgae, 
then to leathery and coarsely branched macroalgae or calcified algae that are unpalatable to most herbivores (Hixon \& Brostoff 1996, McClanahan 2000, Diaz-Pulido et al. 2007). Thus, it is important to identify how different herbivores influence algal composition and succession on coral reefs, and what this means in the context of preventing shifts to macroalgal dominance (Hughes 1994, McClanahan et al. 2001, Hoey \& Bellwood 2009).

The functional roles herbivores play on coral reefs may reflect their mobility (Sandin \& McNamara 2012), feeding preferences (Mantyka \& Bellwood 2007), lifehistory characteristics (Russ \& Alcala 1998), or resistance and recovery responses to disturbances, such as fishing and coral bleaching (McClanahan et al. 2007, Graham et al. 2011, McClanahan \& Humphries 2012). These traits ultimately affect competition, size, and predation risk, all of which are important factors that influence the distribution and functional role of a herbivore in an ecosystem (Werner \& Anholt 1993, Dulvy et al. 2004). In Kenya, scrapers and grazers are fishes that may play similar roles in contributing to coral reef resilience by preventing the establishment of macroalgae and providing areas of clean substratum for coral recruitment (Cheal et al. 2010). Their activities can also facilitate the establishment of CCA, which are important for reef growth (Steneck 1983, McClanahan 1997, O'Leary \& McClanahan 2010). Scrapers feed primarily on epilithic algal turf while closely cropping or scraping the reef surface (Bellwood \& Choat 1990). Grazers feed on a similar diet to scrapers, and detritivores on a combination of turf, sediment, and plankton; however, grazers and detritivores can have similar impacts on algal dynamics (Marshell \& Mumby 2012).

As sea urchins are spatially constrained organisms with different feeding properties from fish, the patterns in algal and coral composition that they are able to mediate may be different from those maintained by fish (O'Leary \& McClanahan 2010, O'Leary et al. 2012). Fish are vagile consumers and more wide ranging than sea urchins, with relatively large home ranges (75 to $300 \mathrm{~m}^{2}$ in the Caribbean; Mumby \& Wabnitz 2002), whereas an individual sea urchin may forage within an area of just $1 \mathrm{~m}^{2}$ on coral reefs (Carpenter 1984). Fish may be selective foragers in these larger areas and select algae based on properties of palatability (Burkepile \& Hay 2008), while sea urchins are less selective and select algae primarily on the basis of accessibility (Ogden \& Lobel 1978, Sandin \& McNamara 2012). This can create a dynamic mosaic of intensely grazed and ungrazed areas on a reef that reflects patchiness in sea urchin abundance. Overall, herbivorous fishes and sea urchins will likely have quite different effects on community structure and ecosystem functioning on coral reefs.

In Kenya, all herbivorous fish species are heavily and indiscriminately exploited while sea urchins are not (McClanahan et al. 2008). Fisheries closures in Kenya represent a management tool intended to prevent overfishing, which will create reefs with variable herbivore abundances and species assemblages (McClanahan et al. 2007). In this study, we used the rapidly emerging establishment of communitymanaged fisheries closures together with older government closures and fished reefs as a 'natural experiment' to examine the differential influence of herbivore assemblages on algal succession. To do this, we used survey techniques coupled with regular estimates of algal abundance (percentage cover) on experimental substrata over a $\sim 390 \mathrm{~d}$ period. We tested 2 hypotheses: (1) that sea urchins and fishes affect algal abundance differently because of differences in feeding mode, and (2) that algal succession will trace similar paths across fisheries management regimes because herbivorous fishes will gradually replace sea urchins as fishing is eliminated on reefs.

\section{MATERIALS AND METHODS}

\section{Study sites}

Kenya's coastline is paralleled by a fringing reef and experiences predictable seasonality. The northeast monsoon season occurs from September to March and is characterized by drier weather and moderate rainfall, river discharge, and wind energy, while solar insolation and air temperatures are high (McClanahan 1988). The southeast monsoon season occurs from April to August and is characterized by thick cloud cover, heavy rains, strong winds, large waves, and fast currents.

Data were collected at 6 sites representing 3 fisheries management types along a $\sim 150 \mathrm{~km}$ stretch of Kenyan coast: 2 younger and smaller communitymanaged fisheries closures, 2 older and larger government-managed closures, and 2 heavily fished reefs (Fig. 1). Sites representing these treatments were interspersed. The community closures, Kuruwitu and Mradi, have been protected from fishing since 2005 and 2010, respectively, and are both $\sim 0.3$ to $0.4 \mathrm{~km}^{2}$ in size. The government closures, Mombasa and Malindi, have been protected from fishing since 1991 and 1968, respectively; Mombasa is 


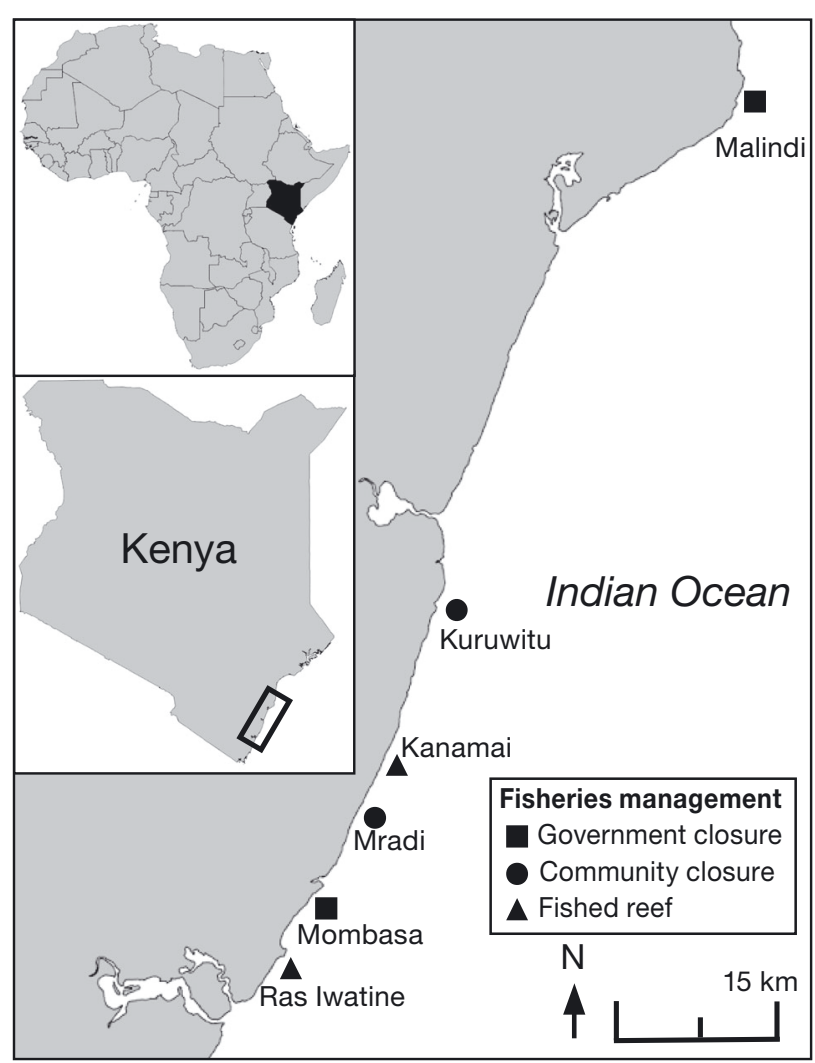

Fig. 1. Study sites located along the coast of east Africa in Kenya. Different shapes represent fisheries management: government closures are no-take zones managed by the Kenya Wildlife Service, community closures are no-take zones managed by fishers, and fished reefs are year-round open access areas

$\sim 6 \mathrm{~km}^{2}$ in size, whereas Malindi is $10 \mathrm{~km}^{2}$. At the fished reefs, Kanamai and Ras Iwatine, fishing is intense and highly unselective with a variety of gear types being used (e.g. spearguns, nets, traps), while beach seines are not used at Ras Iwatine. Sites included coral and algae-dominated areas in backreef lagoons that are protected from strong waves.

\section{Existing herbivore and benthic community composition}

Sea urchins were identified to the species level and counted in $10 \mathrm{~m}^{2}$, haphazardly placed plots ( $\mathrm{n}=9$ to 18 site $^{-1}$ ). Wet weight was estimated by multiplying average numbers of individuals by average wet weights per species using values from McClanahan \& Shafir (1990). Non-herbivorous fishes were counted and identified to family, and size (total length, TL) estimated to the nearest $10 \mathrm{~cm}$ by underwater visual census (via snorkel) using 2 to 4 haphazardly placed replicate belt transects $(5 \times 100 \mathrm{~m})$ per site. Herbivorous fishes were counted and identified to species, and size estimated to the nearest $5 \mathrm{~cm}$ TL in separate passes along the same transects. Scarid species (parrotfishes) $<10 \mathrm{~cm}$ TL were grouped together as 'juveniles' due to the difficulty of identifying them to species in the field. Transects were conducted during neap tides when the water was between $\sim 1$ and $4 \mathrm{~m}$ deep. Small and cryptic taxa, such as blennies, tobies, and gobies, were recorded but probably underestimated (Ackerman et al. 2004). Mass was determined by converting fish counts to biomass using published length-weight relationships (Letourneur et al. 1998, Froese \& Pauly 2006). Herbivorous fishes were assigned to feeding groups (scrapers, grazers, browsers) based on published information on diets (Froese \& Pauly 2006, Green et al. 2009). Grazers and detritivores were combined into one functional group because they have been shown to have similar influences on algae (Marshell \& Mumby 2012). There were no excavating fishes (parrotfishes $>45 \mathrm{~cm}$ ) at these reefs and therefore all parrotfishes were considered scrapers.

Benthic cover was surveyed using haphazardly placed, $10 \mathrm{~m}$ line-intercept transects $\left(\mathrm{n}=9\right.$ site $\left.^{-1}\right)$. The distances covered by major benthic components (hard coral, turf algae, CCA, and erect macroalgae) underlying each transect line were measured to the nearest centimeter. Macroalgae were further identified to the genus level, and percentage cover was calculated as the sum of the lengths divided by the total transect length.

\section{Algal dynamics and succession on experimental substrata}

Experimental substrata (algal growth plates) were made from $\sim 2.5 \mathrm{~cm}$ cross-sections of dead massive Porites coral (mean plate size \pm SE was $184 \pm 11 \mathrm{~cm}^{2}$; $\mathrm{n}=288$ plates). Plates had flat surfaces but irregularly shaped edges. Holes were drilled in individual plates allowing them to be attached to plastic cage flooring. Plates were deployed in sets of 4 , attached at least $5 \mathrm{~cm}$ apart to the same piece of flooring to form a single replicate. To allow access to the plates by different groups of herbivores, 3 experimental treatments were created: (1) cage treatments, which represented a control (for site-specific differences in environmental variables), or plates that are not grazed by fishes or sea urchins, (2) fence treatments that allowed herbivory only by fishes, and (3) open 
treatments that allowed herbivory by both fishes and sea urchins. Cages and fences were made from plastic mesh material $(2.5 \times 2.5 \mathrm{~cm}$ square holes $)$ and attached to bare substratum using U-bolts. Cages were approximately $1 \times 1 \times 0.5 \mathrm{~m}(\mathrm{~L} \times \mathrm{W} \times \mathrm{H})$ in size. Previous work showed that cages similar to these had no significant effect on algal standing crop or species composition other than the effect of excluding grazers (Scott \& Russ 1987). At each reef site, treatments were deployed in 4 blocks, each including 1 replicate from each cage, fence, and open treatment (Fig. S1 in the Supplement at www.int-res.com/articles/suppl/ m504p119_supp.pdf). Blocks were placed >20 m apart from one another, and treatments within blocks were $<3 \mathrm{~m}$ apart. Areas for deployment were typical of the larger reef areas and away from damselfish territories.

The experiment began during the northeast monsoon season between September and October 2011. This is a time when bare substratum is most likely to occur because it is just after the seasonal peak in wave energy and most likely to resemble the natural seasonal process of succession (McClanahan 1988, 1997).

The algal communities growing on the plates were digitally photographed at each site every 6 to $8 \mathrm{wk}$; samples were taken a total of 7 times over the $\sim 390 \mathrm{~d}$ duration of the experiment. Photographs were processed and percent composition of algal turf, fleshy algae, calcareous algae, and CCA was determined using a stratified random point-intercept method ( $\mathrm{n}=$ 50 points plate ${ }^{-1}$ ) with digital photography software. Fleshy algae were further identified to the genus level as being Sargassum, Padina, Hypnea, Dictyota, Turbinaria, Cystoseira, or placed in an 'other' category. The approach involved sacrificial pseudoreplication (Hurlbert 1984), and average values of algal cover for the 4 plates within a replicate were subsequently used in the analyses.

\section{Fish feeding impact}

To quantify feeding on the algal growth plates, stationary underwater video cameras (GoPro) were used. Cameras were deployed at each site and positioned 1 to $2 \mathrm{~m}$ from a haphazardly selected open treatment. Filming commenced and continued without disturbance for $\sim 4 \mathrm{~h}$, and between 15 and 20 repetitions were conducted at each site using different replicates (15 to 20 repetitions $\times 4 \mathrm{~h}=60$ to $80 \mathrm{~h}$ footage site ${ }^{-1}$ ). All video footage was viewed, and the number of bites taken on the plates by each fish species and the sizes (TL) of these fish was recorded and standardized to bites taken per hour. Estimates of fish size were calibrated by placing an object of known length in front of the treatment at the beginning of each video. To account for body size-related variation in the impact of individual bites, a massstandardized bite impact was calculated as the product of fish body mass and number of bites taken by each fish (Hoey \& Bellwood 2009).

\section{Statistical analyses}

We used separate 1-way analyses of variance (ANOVAs) to test for an effect of fisheries management (fished, community closure, government closure) on: total fish biomass, herbivorous fish biomass, sea urchin biomass, and herbivorous fish functional group biomass (scrapers, browsers, grazers). Using 2-way ANOVAs, we tested for an effect of fisheries management and treatment (cage, fence, open), and their interaction, on the percentage cover of algal groups on the experimental substrata. Algal groups tested were: algal turf, upright macroalgae (all macroalgal species combined), CCA, Dictyota, Padina, Sargassum, Turbinaria, Hypnea, and Cystoseira. The 'other' macroalgae category was excluded from analyses because it accounted for $<3 \%$ of overall abundance. Data used in these models were from the first (Day 0) and last sampling event ( Day 390). Site was nested within fisheries management for all models, and where necessary, data were log-transformed to improve the spread of the data and to meet model assumptions of normality and homoscedasticity. We also used 1-way ANOVAs to test for an effect of fisheries management on the feeding impacts of herbivorous fishes (scrapers, browsers, grazers). These models were based on the proportion of mass-standardized bites taken per hour from stationary underwater video recordings. All model diagnostics were performed visually using frequency histograms, funnel plots, and quantile-quantile (Q-Q) plots, and the final models met the assumptions of normality and homogeneity of residuals. Significant models were followed by individual contrasts using Tukey tests to identify pairwise differences.

We estimated grazing strength on upright macroalgae using the natural log-response ratio (LRR; Osenberg et al. 1997). LRRs are a commonly used effect metric because they are amenable to biological interpretation, are proportionally symmetrical, and have a sampling distribution that approximates normality (Hedges et al. 1999). Here, LRRs were calculated as: 


$$
\mathrm{LRR}=\ln \left(\frac{A_{\mathrm{C}}}{A_{\mathrm{T}}}\right)
$$

where $A_{\mathrm{C}}$ is the abundance (\% cover) of the cage treatment and $A_{\mathrm{T}}$ is the abundance (\% cover) of either the fence or open treatment. Positive LRR values indicate a reduction of macroalgae by consumption, while negative values of LRR indicate that grazers promoted the abundance of macroalgae through fertilization. Zero values of LRR indicate no difference in macroalgal abundance from control (cage) treatments, or no grazing or fertilization effect. We then used 1-way ANOVAs of the LRR values to determine whether there was a significant grazing or fertilization effect at the fence and open treatments.

To determine how treatment and fisheries management affected algal community structure through time, we used a multivariate randomization procedure to create a matrix of Bray-Curtis similarity measures (for the final sampling event as well as one in the middle of the experiment; $\sim 180$ and 390 d). We analyzed these distance matrices using permutational analysis of variance (PERMANOVA; $\mathrm{n}=999$ permutations) and used non-metric multidimensional scaling (MDS) ordination to visualize similarities in algal community structure. We then used correlation-based principal component analysis (PCA) on Euclidean distances with data from the open treatments at the final sampling event. Multivariate homogeneity of the treatments was confirmed using Levene's test for equality of variances (Levene 1960). All data analyses were performed using the program ' $\mathrm{R}$ ' (v. 2.15.1; R Development Core Team 2013).

\section{RESULTS}

\section{Existing herbivore and benthic community composition}

The fished reefs, Kanamai and Ras Iwatine, had low abundances of fish, total fish biomass being only 70.6 and $96.5 \mathrm{~kg} \mathrm{ha}^{-1}$, respectively. For Kanamai, herbivores comprised $4.6 \mathrm{~kg} \mathrm{ha}^{-1}$, or $7.8 \%$, of total fish biomass; for Ras Iwatine they contributed $12.9 \mathrm{~kg}$ $\mathrm{ha}^{-1}$, or $13.4 \%$ (see Table S1 in the Supplement at www.int-res.com/articles/suppl/m504p119_supp. pdf). Sea urchins were abundant at these 2 sites with a mean biomass of $6095 \mathrm{~kg} \mathrm{ha}^{-1}$ and $4401 \mathrm{~kg} \mathrm{ha}^{-1}$ at Kanamai and Ras Iwatine, respectively. At Kanamai, most urchins were Echinometra mathaei $(4530 \mathrm{~kg}$ $\mathrm{ha}^{-1}$ ), whereas at Ras Iwatine most were Echinothrix diadema (2956 kg ha-1).
The community closures, Kuruwitu and Mradi, had more fish biomass but fewer urchins than the fished reefs. Kuruwitu had a total fish biomass of $364 \mathrm{~kg} \mathrm{ha}^{-1}$ and a sea urchin biomass of $2591 \mathrm{~kg} \mathrm{ha}^{-1}$, whereas Mradi had $440 \mathrm{~kg} \mathrm{ha}^{-1}$ of fish and $2664 \mathrm{~kg} \mathrm{ha}^{-1}$ sea urchin biomass. At Kuruwitu, herbivores accounted for $49 \%$ of the total fish biomass, or $178 \mathrm{~kg} \mathrm{ha}^{-1}$. The majority of these herbivores were grazers with $<10 \%$ being browsers or scrapers. Sea urchins at Kuruwitu were mostly either Diadema spp. or Echinometra mathaei. Mradi had $209 \mathrm{~kg} \mathrm{ha}^{-1}$ of herbivorous fishes, forming $47 \%$ of its total fish biomass. Much like Kuruwitu, the majority of the herbivorous fishes at Mradi were grazers, with $<5 \%$ being browsers or scrapers. The sea urchin community at Mradi consisted of mostly Echinothrix diadema (1272 kg ha $\left.{ }^{-1}\right)$.

Mombasa and Malindi, the government closures, had the highest fish biomass and lowest sea urchin biomass. Mombasa had a mean fish biomass of $954 \mathrm{~kg} \mathrm{ha}^{-1}$, with $460 \mathrm{~kg} \mathrm{ha}^{-1}$ of that being herbivores, or $48 \%$. Herbivorous fishes at Mombasa were dominated by browsers $\left(187 \mathrm{~kg} \mathrm{ha}^{-1}\right)$, followed by grazers (161 kg ha-1), and scrapers (112 kg ha $\left.{ }^{-1}\right)$. Malindi had the highest fish biomass of all sites with $1165 \mathrm{~kg} \mathrm{ha}^{-1}$, of which $578 \mathrm{~kg} \mathrm{ha}^{-1}$, or almost $50 \%$ were herbivores. Herbivorous fish functional groups were somewhat evenly distributed at Malindi, with biomass ranging between 120 and $172 \mathrm{~kg} \mathrm{ha}^{-1}$. The sea urchin community at Mombasa was composed of mostly Echinothrix diadema and had an overall biomass of $1411 \mathrm{~kg} \mathrm{ha}^{-1}$. With a total biomass of $60 \mathrm{~kg}$ $\mathrm{ha}^{-1}$, Malindi had the fewest sea urchins of any site.

Existing benthic cover varied among sites and fisheries management, with the highest hard coral and lowest macroalgal cover at Mradi and Kanamai (hard coral: 46 and $34.8 \%$, macroalgae: 8.5 and $0.9 \%$, respectively; Table 1). Ras Iwatine had the lowest hard coral abundance with $7.1 \%$, and Mombasa had the highest macroalgal abundance with $25.7 \%$. CCA was highest at Malindi with $20.4 \%$ cover. Algal turf abundance was highest at the fished reefs, Kanamai and Ras Iwatine, with $>42 \%$ cover. Macroalgal genera varied by site and management; Sargassum was most abundant at Mombasa (23.2\%) and Turbinaria was most abundant at Malindi $(9 \%)$. Other macroalgal genera comprised never $>5 \%$ of cover at sites.

Model results indicated significant differences among all fisheries management types for the biomass of all fish and herbivorous fish $(p<0.01$ in all cases; Table 2). Although sea urchins generally decreased in biomass as fish increased, the difference was only statistically significant when comparing fished reefs to government closures $(p=0.021)$. 

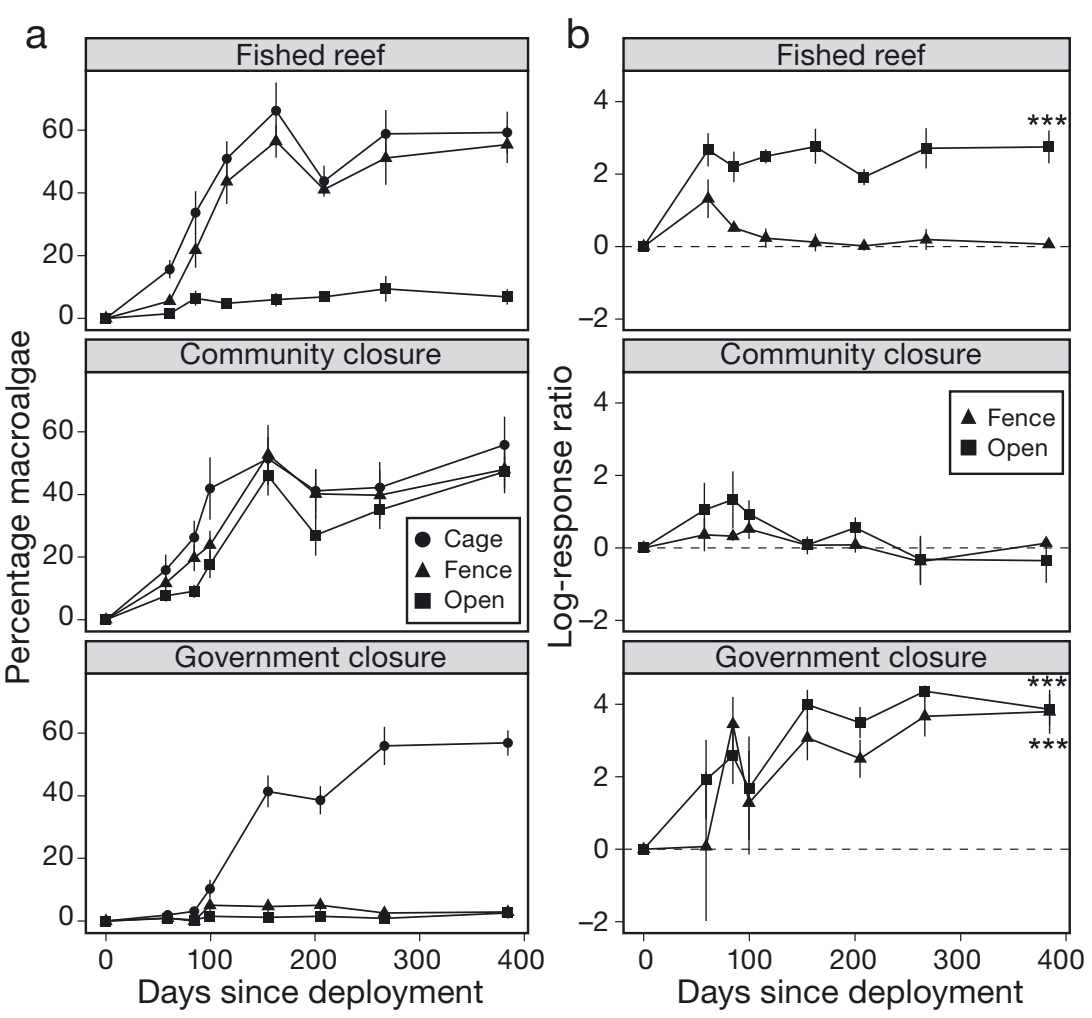

Fig. 2. Time series of the mean $( \pm \mathrm{SE})$ (a) percentage cover of macroalgae and (b) log-response ratio (LRR) on the experimental substrata over $\sim 390 \mathrm{~d}$ by treatment (cage, fence, open) and fisheries management type. Positive values of LRR indicate a reduction of macroalgal abundance by consumption, negative values of LRR indicate that grazers promote the abundance of macroalgae through fertilization, and zero values indicate no difference in macroalgal abundance from control (cage) treatments. ${ }^{* * *} \mathrm{p}<0.001$ (from ANOVAs of the final sampling event)

Scraper and browser fish biomass was significantly higher at government closures, but there was no difference between fished reefs and community closures (Table 2). Grazer fish biomass was significantly higher at government closures and community closures when compared with fished reefs, but there was no significant difference between government and community closures (Table 2). Fisheries management was a poor predictor $(p>0.05)$ for most benthic categories, with the exception of algal turf (which was more abundant at fished sites than in both types of closures), and CCA (which was more abundant at government closures than in other management types) (Table S2). Macroalgal genera did not differ by management type except for Turbinaria, which was more abundant at government closures.

\section{Algal dynamics and succession on experimental substrata}

Percentage cover and LRRs of total upright macroalgae showed distinct trends through time among treatments and fisheries management types (Fig. 2); however, responses of individual macroalgal genera were less clear through time (Fig. 3). CCA cover (open treatments only) was significantly greater at the government closures than other management types $(\mathrm{p}<$ 0.001 ) and increased through time to reach an overall percentage cover $>20 \%$ (Fig. 4).

Two-way ANOVAs revealed a significant interaction term for 6 of the 9 algal groups, indicating that

Table 1. Mean abundance ( $\%$ cover $\pm \mathrm{SE}$ ) of the major substratum categories and macroalgal genera at each of the 6 study sites and by fisheries management type

\begin{tabular}{|c|c|c|c|c|c|c|}
\hline & \multicolumn{2}{|c|}{ Fished reef } & \multicolumn{2}{|c|}{ Community closure } & \multicolumn{2}{|c|}{ Government closure } \\
\hline & Kanamai & Ras Iwatine & Kuruwitu & Mradi & Mombasa & Malindi \\
\hline \multicolumn{7}{|l|}{ Major substratum } \\
\hline Hard coral & $34.77 \pm 6.79$ & $7.1 \pm 4.56$ & $26.17 \pm 8.38$ & $46.01 \pm 13.12$ & $20.23 \pm 10.08$ & $27.17 \pm 14.77$ \\
\hline Algal turf & $42.6 \pm 9.48$ & $42.80 \pm 12.77$ & $37.33 \pm 13$ & $21.05 \pm 16.59$ & $33.18 \pm 12.60$ & $24.86 \pm 15.49$ \\
\hline Macroalgae & $0.93 \pm 2.01$ & $13.88 \pm 11.62$ & $12.44 \pm 7.82$ & $8.50 \pm 6.27$ & $25.73 \pm 7.95$ & $9.30 \pm 6.34$ \\
\hline Crustose coralline algae & $1.77 \pm 2.06$ & $8.56 \pm 2.61$ & $3.18 \pm 2.47$ & $10.21 \pm 5.35$ & $13.16 \pm 6.17$ & $20.44 \pm 7.94$ \\
\hline \multicolumn{7}{|l|}{ Macroalgal genus } \\
\hline Cystoseira & $0 \pm 0$ & $0 \pm 0$ & $1.57 \pm 1.24$ & $0.25 \pm 0.25$ & $0 \pm 0$ & $0 \pm 0$ \\
\hline Dictyota & $0.03 \pm 0.05$ & $1.25 \pm 1.40$ & $0.75 \pm 0.54$ & $1.21 \pm 0.02$ & $0.45 \pm 0.35$ & $0.09 \pm 0.13$ \\
\hline Hypnea & $0.04 \pm 0.06$ & $1.35 \pm 0.54$ & $0.41 \pm 0.37$ & $3.62 \pm 2.53$ & $0 \pm 0$ & $0.1 \pm 0.0$ \\
\hline Padina & $0.25 \pm 0.16$ & $3.63 \pm 0.37$ & $1.00 \pm 0.81$ & $1.24 \pm 0.20$ & $0.03 \pm 0.04$ & $0 \pm 0$ \\
\hline Sargassum & $0.07 \pm 0.10$ & $7.11 \pm 1.37$ & $4.93 \pm 1.37$ & $0.67 \pm 0.67$ & $23.17 \pm 2.66$ & $0 \pm 0$ \\
\hline Turbinaria & $0.50 \pm 0.53$ & $0.52 \pm 0.37$ & $1.00 \pm 0.11$ & $0.83 \pm 0.83$ & $1.95 \pm 0.03$ & $9.04 \pm 2.24$ \\
\hline
\end{tabular}


Table 2. Pairwise comparisons of fish and sea urchin communities by fisheries management type (fished reefs, community closures, government closures) from ANOVAs of biomass $\left(\mathrm{kg} \mathrm{ha}^{-1}\right)$ data. All fish represent both herbivorous and nonherbivorous fishes. Sea urchin data were log-transformed to meet assumptions of normality and homoscedasticity. ${ }^{*} \mathrm{p}<0.05,{ }^{* *} \mathrm{p}<0.01,{ }^{* * *} \mathrm{p}<0.001$

\begin{tabular}{|c|c|c|c|}
\hline & Estimate & $Z$ & $\mathrm{p}$ \\
\hline \multicolumn{4}{|l|}{ All fish } \\
\hline Fished vs. government & -976.00 & -12.87 & $* * *$ \\
\hline Community vs. government & -657.28 & -8.67 & $* * *$ \\
\hline Community vs. fished & 318.72 & 4.20 & $* *$ \\
\hline \multicolumn{4}{|l|}{ Sea urchin } \\
\hline Fished vs. government & 2.93 & 3.46 & ${ }^{*}$ \\
\hline Community vs. government & 2.26 & 2.47 & 0.088 \\
\hline Community vs. fished & -0.67 & -0.73 & 0.751 \\
\hline \multicolumn{4}{|l|}{ Herbivorous fish } \\
\hline Fished vs. government & -508.76 & -14.83 & $* * *$ \\
\hline Community vs. government & -324.34 & -9.45 & $* * *$ \\
\hline Community vs. fished & 184.42 & 5.38 & $* * *$ \\
\hline \multicolumn{4}{|l|}{ Scraper } \\
\hline Fished vs. government & -111.01 & -7.71 & $* * *$ \\
\hline Community vs. government & -106.83 & -7.42 & $* * *$ \\
\hline Community vs. fished & 4.18 & 0.29 & 0.955 \\
\hline \multicolumn{4}{|l|}{ Browser } \\
\hline Fished vs. government & -183.65 & -6.38 & $* * *$ \\
\hline Community vs. government & -165.58 & -5.75 & $* * *$ \\
\hline Community vs, fished & 18.07 & 0.63 & 0.809 \\
\hline \multicolumn{4}{|l|}{ Grazer } \\
\hline Fished vs. government & -214.10 & -6.91 & $* * *$ \\
\hline Community vs. government & -51.93 & -1.68 & 0.266 \\
\hline Community vs. fished & 162.17 & 5.23 & $* * *$ \\
\hline
\end{tabular}

significant effects $(p<0.05)$ of treatment type on the abundance of algal groups depend on the fisheries management regime (Table S3). This trend was true for all groups except Turbinaria, Hypnea, and Padina.

At the fished reefs, succession of macroalgal genera in the cage and fence treatments mostly began with Padina and Hypnea dominating the assemblage, but transitioned into a more mixed assemblage with increasing cover of Sargassum as the experiment progressed (Fig. 3). Total upright macroalgae in the cage and fence treatments reached and remained around or above $40 \%$ cover after $\sim 100 \mathrm{~d}$ (Fig. 2a). The open treatment at these sites developed very little macroalgal cover through time, remaining consistently at or below $\sim 10 \%$. There were slight fluctuations in percentage cover in the cage and fence treatments around $\sim 210 \mathrm{~d}$, when the stronger winds and currents of the southeast mon- soon season may have caused a reduction in the already established macroalgal community. The ANOVA by treatment for percentage cover of total upright macroalgae was significant $(F=19.31$; p < 0.01 ), and pairwise comparisons indicated that the fence and cage treatments at the fished reefs were not significantly different from one another $(\mathrm{p}=$ 0.894); however, open treatments were significantly lower than both fence and cage treatments $(p<$ 0.001; Table S4). The ANOVAs of LRRs corroborated these findings with a significant grazing effect on total upright macroalgae at the open treatment $(F=$ 36.31; $\mathrm{p}<0.001)$, but not the fence treatment at the fished reefs $(F=0.62 ; \mathrm{p}=0.443$; Fig. $2 \mathrm{~b})$.

Padina and Hypnea, with Sargassum and Cystoseira, dominated succession of macroalgal genera for all treatments at the community closures and increased through time (Fig. 3). Total upright macroalgae in all treatments traced similar successional trajectories; there was an immediate increase in total upright macroalgae at all treatments that reached the highest levels around $\sim 150 \mathrm{~d}$, and then again at the end of the experiment at $\sim 50 \%$ cover (Fig. 2a). Similar to the fished reefs, there was a slight decrease in percentage cover between $\sim 200$ and $\sim 300 \mathrm{~d}$, most likely due to seasonal monsoon effects. The ANOVA by treatment for percentage cover of total upright macroalgae was not significant $(F=1.16, \mathrm{p}=0.532$; Table S4), and LRRs corroborated this finding with no significant grazing or fertilization effect (open: $F=$ $0.33, p=0.577$; fence: $F=1.46, p=0.247$; Fig. $2 b$ ).

At the government closure sites, succession of macroalgal genera in cage treatments began mostly with Padina, Cystoseira, and Hypnea, then transitioned into a mixed assemblage, with Sargassum becoming dominant and Turbinaria present (Fig. 3). Total upright macroalgae in the cage treatments increased and were at or above $\sim 40 \%$ cover after $\sim 150$ d (Fig. 2a). Total upright macroalgae in the fence and open treatments remained low for the duration of the experiment, and percentage cover never exceeded $\sim 10 \%$. The ANOVA by treatment for percentage cover of total upright macroalgae was significant $(F=30.87 ; \mathrm{p}<0.001)$, and pairwise comparisons indicated a significant difference between both the open and fence treatments with the cage treatment $(\mathrm{p}<0.001)$; however, fence and open treatments were not significantly different from one another $(\mathrm{p}=$ 0.997; Table S4). The ANOVAs of LRRs corroborated these findings and indicated a significant grazing effect of total upright macroalgae in both fence $(F=$ 38.97; $\mathrm{p}<0.001)$ and open treatments $(F=83.22 ; \mathrm{p}<$ 0.001; Fig. 2b). 

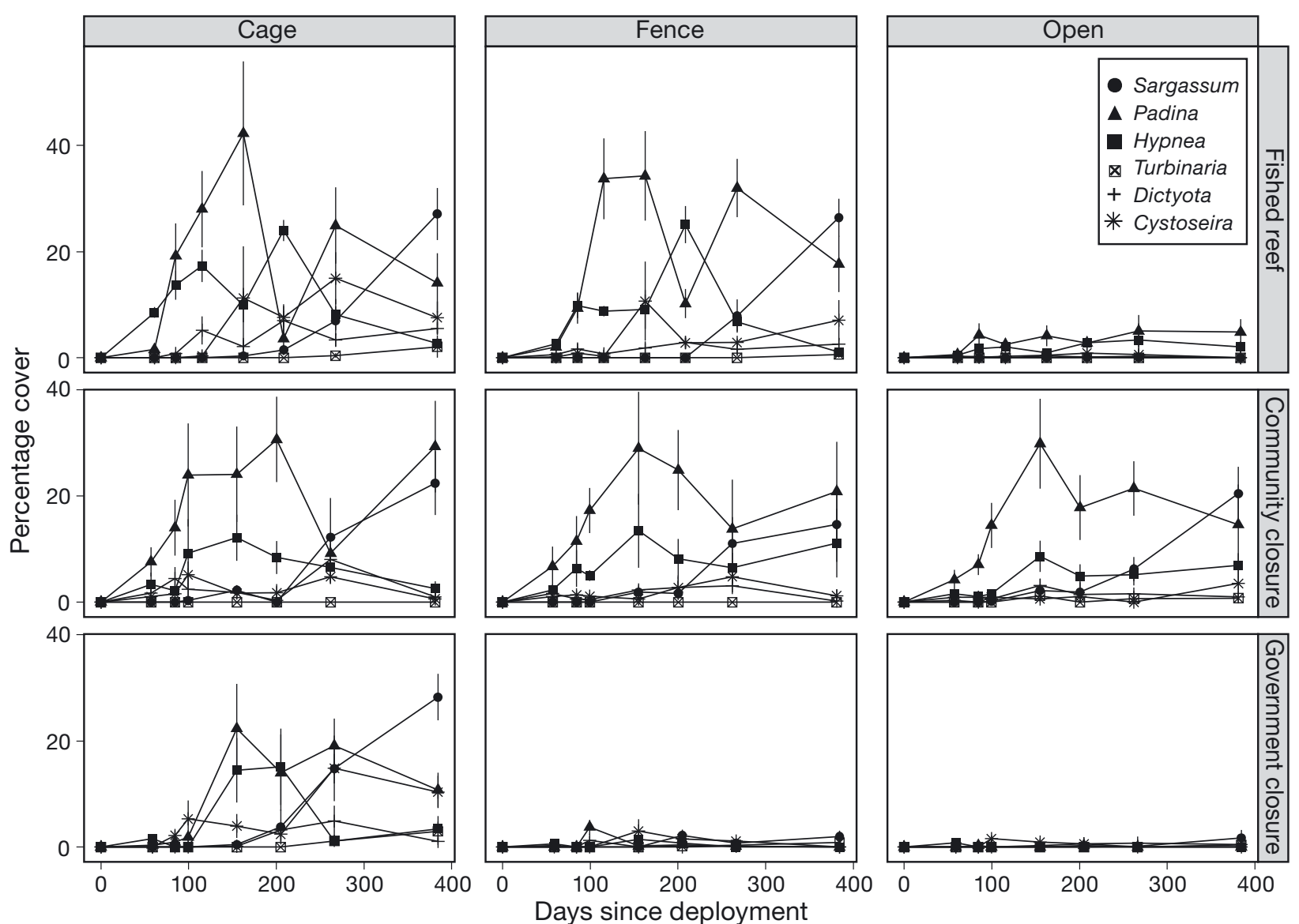

Fig. 3. Time series of mean percentage cover $( \pm \mathrm{SE})$ of macroalgal genera by treatment type (cage, fence, open) and fisheries management type (fished reefs, community closures, government closures) on experimental substrata at 6 study sites in Kenya over $\sim 390 \mathrm{~d}$. If the total percentage cover is $<100$, the remaining algal cover is turf

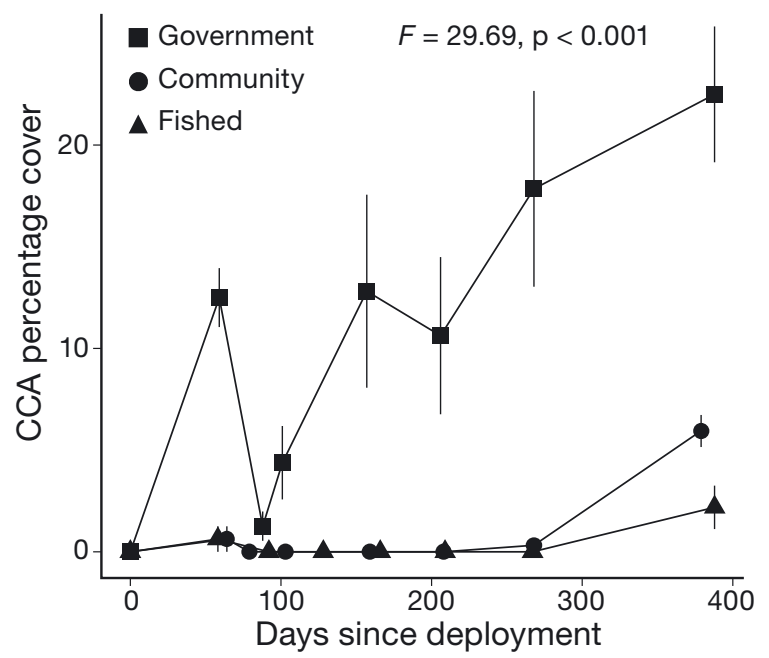

Fig. 4. Time series of mean percentage cover $( \pm \mathrm{SE})$ of crustose coralline algae (CCA) by fisheries management type (fished reefs, community closures, government closures) on experimental substrata over $\sim 390$ d. Data are from open treatments only. ANOVA results from the comparison of management types are for the final sampling event
Results from MDS showed that algal community structure in the cage treatment had a high variance and sites failed to cluster by fisheries management in axis space at either $\sim 180$ or $\sim 390$ d (Fig. S2). Model results indicated poor explanatory power of these plots, and the results were not significant ( 180 d: $\mathrm{R}^{2}=0.123, \mathrm{p}=0.205 ; \sim 390 \mathrm{~d}: \mathrm{R}^{2}=0.120 ; \mathrm{p}=0.203$ ). For the fence treatment, there was a differentiation among all 3 fisheries management types at both $~ 180$ and $\sim 390 \mathrm{~d}$. This was driven by the presence of turf algae at government closures, and macroalgae at community closures and fished reefs. These plots explained $>40 \%$ of the variation in the models and, although explanatory power was low, both were significant $\left(\sim 180 \mathrm{~d}: \mathrm{R}^{2}=0.407, \mathrm{p}<0.001 ; \sim 390 \mathrm{~d}: \mathrm{R}^{2}=\right.$ $0.464, \mathrm{p}<0.001)$. The open treatment showed the clearest effect of management type. Government closures and fished reefs tended to cluster together, being characterized by algal turf and, in the case of government closures, CCA, whereas community closures were different, with a high abundance of 
macroalgae at both $\sim 180$ and $\sim 390 \mathrm{~d}$. Model results indicated stronger explanatory power for these plots, with $>50 \%$ of the variance explained by the model $\left(\sim 180\right.$ d: $R^{2}=0.562, p<0.001 ; \sim 390$ d: $R^{2}=0.498, p<$ 0.001; Fig. S2).

The first principal component axis (PC1) of the PCA differentiated fisheries management by herbivore group, with fishes (scrapers, browsers, grazers) at negative PC1 scores and sea urchins at positive PC1 scores (Fig. 5). The second principal component axis (PC2) differentiated fisheries management along a gradient from algal communities, with turf and CCA at negative PC2 scores, to those with macroalgae at positive PC2 scores. PCA results show overlap and suggest fisheries management mediated algal assemblages through herbivore composition: turf algae were representative of fished reefs because of sea urchins; turf algae and CCA were representative of government closures because of scrapers (and browsers); and macroalgae dominated in community closures because of intermediate levels of sea urchins and the presence of very few scrapers and browsers.

\section{Fish feeding impact}

Feeding on the algal growth plates was dominated by grazers, which accounted for $75 \%$ of all mass standardized bites (Fig. S3). Most bites occurred at the government closures, where fish of 16 to $20 \mathrm{~cm}$ TL had the greatest contribution. Scrapers accounted for nearly $22 \%$ of all mass standardized bites, and these were caused primarily at the government closure sites by fish between 16 and $25 \mathrm{~cm}$ TL. Browsers accounted for $<3 \%$ of all mass standardized bites on the plates. Model results indicated a significant effect of fisheries management on the bite impact of scrapers $(F=195.15 ; \mathrm{p}<0.001)$ and grazers $(F=66.18 ; \mathrm{p}<$ $0.001)$, but not browsers $(F=0.61$; $p=0.434)$. However, it should be pointed out that the algal growth plates within government closures experienced high rates of grazing by scraping and grazing fishes and thus had little upright macroalgae. Even though browsing herbivorous fishes were abundant within the government closures, one would expect low rates of herbivory by browsers under such circumstances (i.e. due to a lack of preferred food), so the lack of effect of management on browser herbivory would be expected. Pairwise comparisons showed that all contrasts between fisheries management types were significant for both scrapers and grazers $(p<0.05$; Table S5).
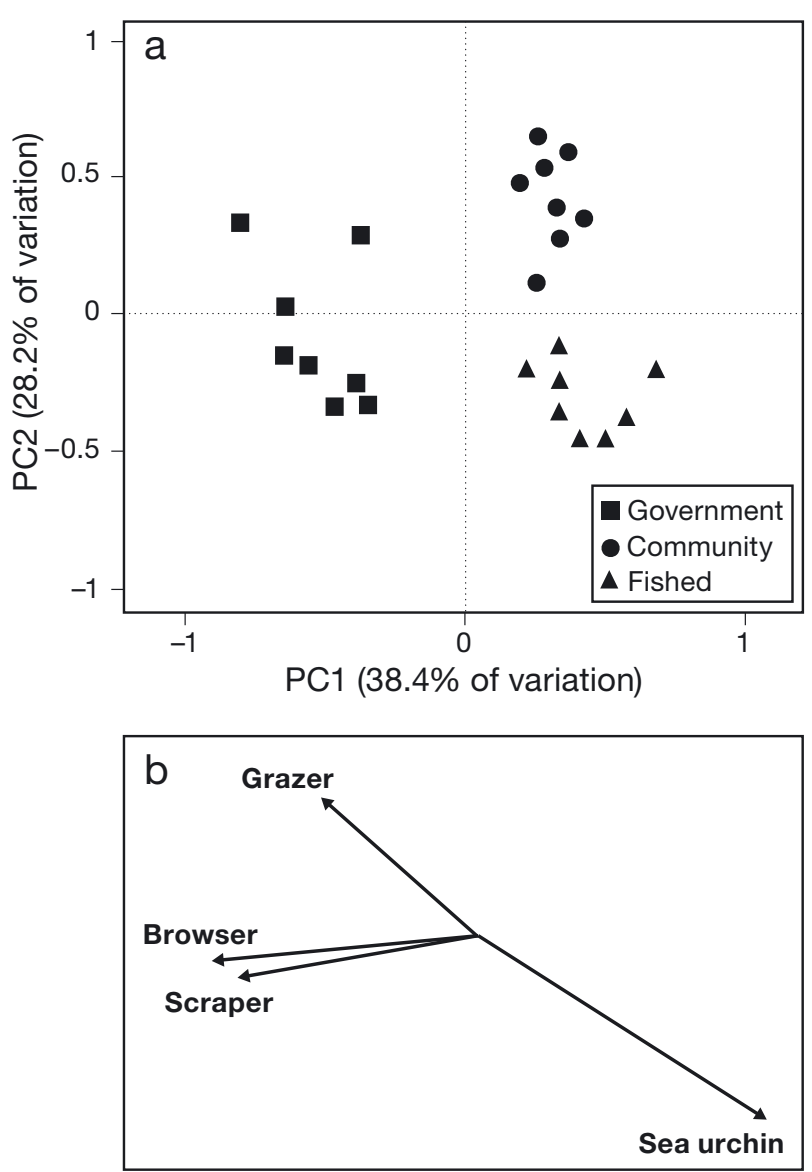

Fig. 5. (a) Spatial variation in algal composition on experimental substrata and (b) relative contribution of herbivores using principal component analysis (PCA) on Euclidean distances. Data points represent open treatments (herbivory by sea urchins and fishes) 390 d after deployment, and different shapes represent fisheries management type (fished reefs, community closures, government closures). Points that are closer together in ordination space are more similar in terms of algal community

\section{DISCUSSION}

Patterns of algal succession on the experimental substrata followed different trajectories in the presence and absence of herbivores and according to management type. Specifically, the results were linked to the grazer assemblages found at the sites under different management regimes: larger scraping (and browsing) fishes were associated with algal turfs and CCA at the older and larger government closures, and sea urchins co-occurred with turfs at the fished reefs. The younger community-managed fisheries closures had intermediate levels of sea urchins and mostly grazer fishes, which allowed algae to quickly transition from turf into assemblages 
dominated by fleshy macroalgae. Here, macroalgae that became established early primarily comprised Hypnea and Padina, followed by a late stage dominated by Sargassum and some Turbinaria. These particular reefs may represent a transitional system of herbivore dominance that exists prior to the full recovery of fish biomass and larger-bodied scrapers in no-take fisheries closures. These results provide further support for other studies that have identified differential grazing effects between sea urchins and fishes (Ogden \& Lobel 1978, McClanahan 1997, O'Leary \& McClanahan 2010). This study also highlights the importance of herbivore species composition, biomass, and feeding impact in preventing algal turf from transitioning to early and then late successional macroalgae species that may be detrimental to coral growth (Rasher \& Hay 2010). Furthermore, creating a complementary grazing guild that is able to prevent macroalgae proliferation (Burkepile \& Hay 2010) may not be achieved immediately after establishment of fisheries closures.

In the absence of sea urchin and fish grazing, as well as in treatments with low levels of grazing, algal succession over the $\sim 390$ d generally progressed from turf to an early dominance by blades and finely branched brown and red algae, including Padina and Hypnea. Following these macroalgae were coarsely branched and leathery macroalgae, such as Sargassum and Turbinaria. This trend is mediated by competitive interactions and life-history characteristics of algae that reflect a species' growth, reproduction, and survival rate (Grime 1977, Huston \& Smith 1987, Duffy \& Hay 1990). The results here agree with lifehistory theory and findings from similar experiments in other regions (e.g. Carpenter 1986, Hixon \& Brostoff 1996, Ceccarelli et al. 2011), indicating that early successional algae invest energy in continuous rapid growth and invade newly opened space first, rather than investing in costly structural and chemical defenses that may mean slower rates of establishment (Duffy \& Hay 1990). A concern for reefs containing a high abundance of these late successional species is that stabilizing feedbacks will strengthen the macroalgae state because they are unpalatable to the majority of herbivores (Hay 1991). This may prevent successful coral recruitment (Kuffner et al. 2006) and compromise reef growth and sustainability (McCook et al. 2001). Preventing algal shifts to dominance by unpalatable macroalgae in this experiment was ultimately dependent on the ability of sea urchins or groups of large-bodied fishes (i.e. scrapers) to maintain a surface of cropped or calcified algae.
In this study, macroalgae colonized substrates rapidly in all treatments where grazing was absent, and reached levels of $\sim 55 \%$ cover within $100 \mathrm{~d}$. These rates are similar to, or slightly greater than, those found in previous experiments at Australian (Great Barrier Reef) and Hawaiian reefs (Hatcher \& Larkum 1983, Scott \& Russ 1987, Hixon \& Brostoff 1996, Smith et al. 2010), but $\sim 20 \%$ lower than those at Caribbean reefs (Carpenter 1986, Morrison 1988, Sotka \& Hay 2009, Ferrari et al. 2012). The number of macroalgal genera also remained relatively high in this experiment at ungrazed treatments, even at the end of the sampling period, compared with other studies. Differences among regions and reefs most likely occur because of biogeographic differences in algal species composition, or differential rates of algal recruitment mediated by surrounding conditions (e.g. UV radiation), propagule dispersal, and herbivore community composition (Stiger \& Payri 1999, Vermeij et al. 2013). Differences in physical forces, such as waves and tides, may also contribute to the heterogeneity between regions, as these factors can sometimes have a stronger effect than herbivory on algal communities (Gaylord et al. 2002, Lefèvre \& Bellwood 2010, Ferrari et al. 2012). Therefore, the specific herbivory levels needed to prevent shifts to macroalgal dominance may be region or site specific, and dependent on local physical and spatial factors (Lefèvre \& Bellwood 2010, Roff \& Mumby 2012).

While the mechanisms by which fishing structures communities may differ among harvesting methods, regions, or ecosystems, understanding the recovery patterns of herbivores can help with conservation and harvest models aimed at increasing reef resilience to phase shifts (Halpern \& Warner 2002, Gaylord et al. 2005). At the reefs in this study area, herbivore composition is primarily a function of fishing intensity (McClanahan et al. 2007). For instance, at heavily fished reefs, sea urchins have few predators and biomass can exceed $4000 \mathrm{~kg} \mathrm{ha}^{-1}$ (McClanahan 1997). The absence of urchin predators is mediated by the removal of large invertebrate-feeding fish species, such as the triggerfish Balistapus undulatus (McClanahan 2000). When fishing is reduced or eliminated, fish biomass may exceed $1200 \mathrm{~kg} \mathrm{ha}^{-1}$, and sea urchins can drop to $<60 \mathrm{~kg} \mathrm{ha}^{-1}$ (McClanahan 1997). At these 2 extremes of fisheries management and herbivore dominance, we found herbivory to be high on the experimental substrata, which were dominated by algal turf (and CCA at the older government closures). We did, however, find that relatively young $(<10 \mathrm{yr}$ since protection) and small $\left(<0.5 \mathrm{~km}^{2}\right)$ community closures had herbivore com- 
munities somewhere between the extremes, with a mixture of sea urchins and fishes. The slow recovery of herbivorous fish biomass, and in particular scraping parrotfishes, in these younger closures led to herbivory levels that were insufficient to prevent macroalgae from establishing and overtaking algal turf, eventually resulting in $>50 \%$ cover. This does not necessarily mean community closures are ineffective management tools and may never have the grazing potential to prevent macroalgal dominance, but they may need more time to develop to be efficient conservation strategies in this area.

If results from these experiments represent reefscale patterns, then in situ algal abundance should be low at the fished sites and within the government closures (due to high sea urchin and fish grazing, respectively), and should be high within the community closures. Fleshy algae, however, developed on experimental substrata at sites where they were uncommon on existing substratum (Kuruwitu, Mradi), and vice versa (Mombasa). Mradi had only 8.5\% macroalgal cover at the site, but macroalgae quickly established on the experimental plates and moved into a late-successional assemblage consisting of larger, canopy-forming species such as Sargassum by the end of the experiment. This discrepancy may be a result of the extremely high coral cover at Mradi (it was more than double that of most of the other study sites) and indicates the site is nearing a threshold where any increase in substratum availability has the potential to enter a macroalgae-dominated state (Steneck \& Dethier 1994, Williams et al. 2001). At Mombasa, experimental plates experienced very little macroalgal cover throughout the experiment, which is in contrast to existing conditions of $25 \%$ macroalgal cover, consisting primarily of Sargassum. Such discrepancies could be a result of previous events at the site where macroalgae were released from grazing pressure and able to develop into a late successional stage consisting of species resistant to herbivory (e.g. 1998 mass coral-bleaching event; McClanahan et al. 2001). Both of these examples stress the importance of the interaction between the histories of sites and existing herbivore assemblages, and how the timing of disturbances may be especially important in determining benthic conditions (Graham et al. 2013). Additionally, algal growth studies such as this one may reflect processes that can establish patterns and not processes that maintain algal distributions.

Grazing by sea urchins in this study prevented the development of fleshy macroalgae; however, sea urchins can have reef erosion rates greater than herbi- vory rates (Carreiro-Silva \& McClanahan 2001) and prevent the establishment of CCA (O'Leary \& McClanahan 2010). This can result in the loss of key services such as the creation of new reef material through calcification, stabilization of reefs through the binding of coral rubble, and a reduction in chemical cues important for coral recruitment (Bak 1976, Morse \& Morse 1996, O'Leary et al. 2012). In this study, fishing on fished reefs may have increased the ability of reefs to resist the establishment and proliferation of macroalgae; however, trade-offs with increased rates of bioerosion should also be considered in the context of reef sustainability and growth.

The establishment of fisheries closures with no additional management action (e.g. gear restrictions) may be insufficient to facilitate the recovery of herbivore populations in some areas, and fishing intensity around closures is likely to be a major factor in the success of closures (Côté et al. 2001, Lester et al. 2009, McClanahan et al. 2009, Pollnac et al. 2010, Daw et al. 2011). Large herbivores have slow recovery times from fishing (Abesamis \& Russ 2005, McClanahan et al. 2007), and these fish are particularly important for herbivory on a reef (Lokrantz et al. 2008). For example, parrotfishes (family Scaridae) $>20 \mathrm{~cm}$ take more than $20 \mathrm{yr}$ to recover (McClanahan et al. 2007) and have a disproportionate impact on algal grazing (Lokrantz et al. 2008). Thus, it is not possible to infer the full benefits of community closures from this study since both study sites (Kuruwitu and Mradi) are $<10$ yr old and parrotfish populations have not fully recovered. One solution to prevent macroalgal phase shifts here could be to complement fisheries closures with alternative management strategies (e.g. gear restrictions), especially when the herbivorous fish communities have already been decimated. For example, removal of certain types of nets (i.e. beach seine) may aid in fish recovery by allowing juveniles and adults time to disperse and shorten the period required for fish to return to reefs in surrounding fisheries closures (Öhman et al. 1998). The herbivore community would then only be able to maintain a macroalgae-free reef once it is beyond a grazing threshold, and this threshold will vary amongst locations (Williams \& Polunin 2001, Mumby et al. 2007).

The recovery of herbivores in fisheries closures may have lasting effects on coral reef functioning by influencing algal succession (Hoey \& Bellwood 2011, McClanahan et al. 2011b). Our data show that largebodied parrotfishes are vital in preventing dominance by unpalatable macroalgae where fishing is prohibited. However, if a reef has only large scraping 
herbivores and no sea urchins or small grazing fishes, macroalgae may still become established (Cheal et al. 2010). Consequently, each herbivore has an important role on the reef that contributes to complementary grazing and the prevention of macroalgal phase shifts (Burkepile \& Hay 2008, 2010, 2011); while large-bodied scraping herbivores are important (Mumby 2006), so are small ones and other functional groups, such as grazers and sea urchins (Ogden \& Lobel 1978, McClanahan \& Shafir 1990, Ceccarelli et al. 2011). At reefs where smaller grazers and sea urchins are dominant, such as the community closures in this study, additional time or management strategies (e.g. gear restrictions) may be necessary to prevent a transition from turf to early and then late successional macroalgae that are better defended against herbivory and erode reef functioning.

Acknowledgements. This work is based upon research supported by the South African Research Chairs Initiative of the Department of Science and Technology and the National Research Foundation to C.D.M. T.R.M. was supported by grants to the Wildlife Conservation Society from the Western Indian Ocean Marine Science Association, the Tiffany, McBean, and John D. and Catherine T. MacArthur Foundations. Kenya's Office of the President provided clearance to do research in Kenya, Kenya Wildlife Service provided permission to work in the government closures, and Kuruwitu Community Organization and Mradi/Kanamai Fishers BMU provided permission to work in their community closures. We are grateful to C. Abunge, C. Katana, M. Muramba, R. Charo, J. Mariara, and E. Darling for field assistance, as well as J. Bosire and J. Uku at Kenya Marine Fisheries Institute for logistical assistance and N. Graham for conversations regarding experimental design.

\section{LITERATURE CITED}

Abesamis RA, Russ GR (2005) Density-dependent spillover from a marine reserve: long-term evidence. Ecol Appl 15: 1798-1812

> Ackerman JL, Bellwood DR, Brown JH (2004) The contribution of small individuals to density-body size relationships: examination of energetic equivalence in reef fishes. Oecologia 139:568-571

Bak R (1976) The growth of coral colonies and the importance of crustose coralline algae and burrowing sponges in relation with carbonate accumulation. Neth J Sea Res 10:285-337

> Bellwood DR, Choat JH (1990) A functional analysis of grazing in parrotfishes (family Scaridae): the ecological implications. Environ Biol Fishes 28:189-214

Burkepile DE, Hay ME (2008) Herbivore species richness and feeding complementarity affect community structure and function on a coral reef. Proc Natl Acad Sci USA 105: 16201-16206

> Burkepile DE, Hay ME (2010) Impact of herbivore identity on algal succession and coral growth on a Caribbean reef. PLoS ONE 5:e8963
Burkepile DE, Hay ME (2011) Feeding complementarity versus redundancy among herbivorous fishes on a Caribbean reef. Coral Reefs 30:351-362

> Carpenter RC (1984) Predator and population density control of homing behavior in the Caribbean echinoid Diadema antillarum. Mar Biol 82:101-108

> Carpenter RC (1986) Partitioning herbivory and its effects on coral reef algal communities. Ecol Monogr 56:345-363

> Carreiro-Silva M, McClanahan TR (2001) Echinoid bioerosion and herbivory on Kenyan coral reefs: the role of protection from fishing. J Exp Mar Biol Ecol 262:133-153

> Ceccarelli D, Jones G, McCook L (2011) Interactions between herbivorous fish guilds and their influence on algal succession on a coastal coral reef. J Exp Mar Biol Ecol 399: 60-67

Cheal A, MacNeil MA, Cripps E, Emslie M, Jonker M, Schaffelke B, Sweatman H (2010) Coral-macroalgal phase shifts or reef resilience: links with diversity and functional roles of herbivorous fishes on the great barrier reef. Coral Reefs 29:1005-1015

Côté IM, Mosqueira I, Reynolds JD (2001) Effects of marine reserve characteristics on the protection of fish populations: a meta-analysis. J Fish Biol 59:178-189

> Daw TM, Cinner JE, McClanahan TR, Graham NAJ, Wilson SK (2011) Design factors and socioeconomic variables associated with ecological responses to fishery closures in the Western Indian Ocean. Coast Manage 39:412-424

> Diaz-Pulido G, Villamil L, Almanza V (2007) Herbivory effects on the morphology of the brown alga Padina boergesenii (Phaeophyta). Phycologia 46:131-136

> Duffy JE, Hay ME (1990) Seaweed adaptations to herbivory. Bioscience 40:368-375

> Dulvy NK, Freckleton RP, Polunin NVC (2004) Coral reef cascades and the indirect effects of predator removal by exploitation. Ecol Lett 7:410-416

Ferrari R, Gonzalez-Rivero M, Ortiz JC, Mumby PJ (2012) Interaction of herbivory and seasonality on the dynamics of Caribbean macroalgae. Coral Reefs 31:683-692

Froese R, Pauly D (eds) (2006) Fishbase. www.fishbase.org (accessed on 26 May 2010)

> Gaylord B, Reed DC, Raimondi PT, Washburn L, McLean SR (2002) A physically based model of macroalgal spore dispersal in the wave and current-dominated nearshore. Ecology 83:1239-1251

> Gaylord B, Gaines SD, Siegel DA, Carr MH (2005) Marine reserves exploit population structure and life history in potentially improving fisheries yields. Ecol Appl 15: 2180-2191

Graham NAJ, Chabanet P, Evans RD, Jennings S and others (2011) Extinction vulnerability of coral reef fishes. Ecol Lett 14:341-348

Graham NAJ, Bellwood DR, Cinner JE, Hughes TP, Norström AV, Nyström M (2013) Managing resilience to reverse phase shifts in coral reefs. Front Ecol Environ 11:541-548

Green AL, Bellwood DR, Choat H (2009) Monitoring functional groups of herbivorous reef fishes as indicators of coral reef resilience. A practical guide for coral reef managers in the Asia Pacific Region. IUCN, Gland. Available at http://cmsdata.iucn.org/downloads/resilience_ herbivorous_monitoring.pdf

> Grime J (1977) Evidence for the existence of three primary strategies in plants and its relevance to ecological and evolutionary theory. Am Nat 111:1169-1194

Halpern BS, Warner RR (2002) Marine reserves have rapid and lasting effects. Ecol Lett 5:361-366 
Hatcher BG, Larkum AWD (1983) An experimental analysis of factors controlling the standing crop of the epilithic algal community on a coral reef. J Exp Mar Biol Ecol 69: 61-84

Hay ME (1991) Fish-seaweed interactions on coral reefs: effects of herbivorous fishes and adaptations of their prey. In: Sale PF (ed) The ecology of fishes on coral reefs. Academic Press, New York, NY, p 96-119

Hay ME (1997) The ecology and evolution of seaweedherbivore interactions on coral reefs. Coral Reefs 16(Suppl):S67-S76

Hedges LV, Gurevitch J, Curtis PS (1999) The meta-analysis of response ratios in experimental ecology. Ecology 80: 1150-1156

> Hixon MA, Brostoff WN (1996) Succession and herbivory: effects of differential fish grazing on Hawaiian coral-reef algae. Ecol Monogr 66:67-90

> Hoey AS, Bellwood DR (2009) Limited functional redundancy in a high diversity system: single species dominates key ecological process on coral reefs. Ecosystems 12:1316-1328

> Hoey AS, Bellwood DR (2011) Suppression of herbivory by macroalgal density: A critical feedback on coral reefs? Ecol Lett 14:267-273

$>$ Hughes TP (1994) Catastrophes, phase shifts, and largescale degradation of a Caribbean coral reef. Science 265: $1547-1551$

> Hughes TP, Rodrigues MJ, Bellwood DR, Ceccarelli D and others (2007) Phase shifts, herbivory, and resilience of coral reefs to climate change. Curr Biol 17:360-365

Hurlbert SH (1984) Pseudoreplication and the design of ecological field experiments. Ecol Monogr 54:187-211

> Huston M, Smith T (1987) Plant succession: life history and competition. Am Nat 130:168-198

$>$ Jones G (1992) Interactions between herbivorous fishes and macro-algae on a temperate rocky reef. J Exp Mar Biol Ecol 159:217-235

Kuffner IB, Walters LJ, Becerro MA, Paul VJ, Ritson-Williams $\mathrm{R}$, Beach KS (2006) Inhibition of coral recruitment by macroalgae and cyanobacteria. Mar Ecol Prog Ser 323: 107-117

Lefèvre CD, Bellwood DR (2010) Seasonality and dynamics in coral reef macroalgae: variation in condition and susceptibility to herbivory. Mar Biol 157:955-965

> Lester SE, Halpern BS, Grorud-Colvert K, Lubchenco J and others (2009) Biological effects within no-take marine reserves: a global synthesis. Mar Ecol Prog Ser 384:33-46

Letourneur Y, Kulbicki M, Labrosse P (1998) Length-weight relationship of fishes from coral reefs and lagoons of New Caledonia - an update. Naga 21:39-46

Levene H (1960) Robust tests for equality of variances. In: Olkin I, Ghurye SG, Hoeffding W, Madow WG, Mann HB (eds) Contributions to probability and statistics, Vol 2. Stanford University Press, Palo Alto, CA, p 278-292

- Lokrantz J, Nystrom M, Thyresson M, Johnansson C (2008) The non-linear relationship between body size and function in parrotfishes. Coral Reefs 27:967-974

> Mantyka CS, Bellwood DR (2007) Macroalgal grazing selectivity among herbivorous coral reef fishes. Mar Ecol Prog Ser 352:177-185

> Marshell A, Mumby P (2012) Revisiting the functional roles of the surgeonfish Acanthurus nigrofuscus and Ctenochaetus striatus. Coral Reefs 31:1093-1101

McClanahan TR (1988) Seasonality in East Africa's coastal waters. Mar Ecol Prog Ser 44:191-199
McClanahan TR (1997) Primary succession of coral-reef algae: differing patterns on fished versus unfished reefs. J Exp Mar Biol Ecol 218:77-102

> McClanahan TR (2000) Recovery of a coral reef keystone predator, Balistapus undulatus, in East African marine parks. Biol Conserv 94:191-198

McClanahan TR, Humphries AT (2012) Differential and slow life-history responses of fishes to coral reef closures. Mar Ecol Prog Ser 469:121-131

McClanahan TR, Shafir SH (1990) Causes and consequences of sea urchin abundance and diversity in Kenyan coral reef lagoons. Oecologia 83:362-370

- McClanahan T, McField M, Huitric M, Bergman K and others (2001) Responses of algae, corals and fish to the reduction of macroalgae in fished and unfished patch reefs of Glovers Reef Atoll, Belize. Coral Reefs 19:367-379

> McClanahan TR, Graham NAJ, Calnan JM, MacNeil MA (2007) Toward pristine biomass: reef fish recovery in coral reef marine protected areas in Kenya. Ecol Appl 17: 1055-1067

McClanahan TR, Hicks CC, Darling SE (2008) Malthusian overfishing and efforts to overcome it on Kenyan coral reefs. Ecol Appl 18:1516-1529

McClanahan TR, Graham NAJ, Wilson S, Letourneur Y, Fisher R (2009) Effects of fisheries closure size, age, and history of compliance on coral reef fish communities in the western Indian Ocean. Mar Ecol Prog Ser 396:99-109

McClanahan TR, Graham NAJ, MacNeil MA, Muthiga NA, Cinner JE, Bruggemann JH, Wilson SK (2011a) Critical thresholds and tangible targets for ecosystem-based management of coral reef fisheries. Proc Natl Acad Sci USA 108:17230-17233

McClanahan TR, Huntington BE, Cokos B (2011b) Coral responses to macroalgal reduction and fishery closure on Caribbean patch reefs. Mar Ecol Prog Ser 437:89-102

McCook L, Jompa J, Diaz-Pulido G (2001) Competition between corals and algae on coral reefs: review of evidence and mechanisms. Coral Reefs 19:400-417

Morrison D (1988) Comparing fish and urchin grazing in shallow and deeper coral reef algal communities. Ecology 69:1367-1382

Morse ANC, Morse DE (1996) Flypapers for coral and other planktonic larvae. Bioscience 46:254-262

Mumby PJ (2006) The impact of exploiting grazers (Scaridae) on the dynamics of Caribbean coral reefs. Ecol Appl 16:747-769

Mumby PJ, Wabnitz CC (2002) Spatial patterns of aggression, territory size, and harem size in five sympatric Caribbean parrotfish species. Environ Biol Fishes 63: 265-279

Mumby PJ, Dahlgren CP, Harborne AR, Kappel CV and others (2006) Fishing, trophic cascades, and the process of grazing on coral reefs. Science 311:98-101

Mumby PJ, Hastings A, Edwards HJ (2007) Thresholds and the resilience of Caribbean coral reefs. Nature 450:98-101

> Nugues MM, Bak RPM (2006) Differential competitive abilities between Caribbean coral species and a brown alga: a year of experiments and a long-term perspective. Mar Ecol Prog Ser 315:75-86

> O'Leary JK, McClanahan TR (2010) Trophic cascades result in large-scale coralline algae loss through differential grazer effects. Ecology 91:3584-3597

O'Leary J, Potts D, Braga J, McClanahan T (2012) Indirect consequences of fishing: reduction of coralline algae suppresses juvenile coral abundance. Coral Reefs 31:547-559 
Ogden JC, Lobel PS (1978) The role of herbivorous fishes and urchins in coral reef communities. Environ Biol Fishes 3: 49-63

Öhman MC, Munday PL, Jones GP, Caley MJ (1998) Settlement strategies and distribution patterns of coral-reef fish. J Exp Mar Biol Ecol 225:219-238

Osenberg CW, Sarnelle O, Cooper SD (1997) Effect size in ecological experiments: the application of biological models in meta-analysis. Am Nat 150:798-812

Pollnac R, Christie P, Cinner JE, Dalton T and others (2010) Marine reserves as linked social-ecological systems. Proc Natl Acad Sci USA 107:18262-18265

R Development Core Team (2013) R: a language and environment for statistical computing. R Foundation for Statistical Computing, Vienna

Rasher DB, Hay ME (2010) Chemically rich seaweeds poison corals when not controlled by herbivores. Proc Natl Acad Sci USA 107:9683-9688

Roff G, Mumby PJ (2012) Global disparity in the resilience of coral reefs. Trends Ecol Evol 27:404-413

Russ GR, Alcala AC (1998) Natural fishing experiments in marine reserves: roles of life history and fishing intensity in family responses. Coral Reefs 17:399-416

Sandin SA, McNamara DE (2012) Spatial dynamics of benthic competition on coral reefs. Oecologia 168: 1079-1090

Scheffer M, Carpenter S, Foley JA, Folke C, Walker B (2001) Catastrophic shifts in ecosystems. Nature 413: 591-596

Schmitz OJ, Hamback PA, Beckerman AP (2000) Trophic cascades in terrestrial systems: a review of the effects of carnivore removal on plants. Am Nat 155:141-153

Editorial responsibility: Janet Ley, St. Petersburg, Florida, USA
Scott FJ, Russ GR (1987) Effects of grazing on species composition of the epilithic algal community on coral reefs of the central Great Barrier Reef. Mar Ecol Prog Ser 39:293-304

Smith JE, Hunter CL, Smith CM (2010) The effects of topdown versus bottom-up control on benthic coral reef community structure. Oecologia 163:497-507

> Sotka EE, Hay ME (2009) Effects of herbivores, nutrient enrichment, and their interactions on macroalgal proliferation and coral growth. Coral Reefs 28:555-568

Steneck RS (1983) Escalating herbivory and resulting adaptive trends in calcareous algal crusts. Paleobiology 9:44-61

> Steneck RS, Dethier MN (1994) A functional group approach to the structure of algal-dominated communities. Oikos 69:476-498

> Stiger V, Payri C (1999) Spatial and temporal patterns of settlement of the brown macroalgae Turbinaria ornata and Sargassum mangarevense in a coral reef on Tahiti. Mar Ecol Prog Ser 191:91-100

Vermeij MJ, van der Heijden RA, Olthuis JG, Marhaver KL, Smith JE, Visser PM (2013) Survival and dispersal of turf algae and macroalgae consumed by herbivorous coral reef fishes. Oecologia 171:417-425

> Werner EE, Anholt BR (1993) Ecological consequences of the trade-off between growth and mortality rates mediated by foraging activity. Am Nat 142:242-272

Williams ID, Polunin NVC (2001) Large-scale associations between macroalgal cover and grazer biomass on middepth reefs in the Caribbean. Coral Reefs 19:358-366

Williams ID, Polunin NVC, Hendrick VJ (2001) Limits to grazing by herbivorous fishes and the impact of low coral cover on macroalgal abundance on a coral reef in Belize. Mar Ecol Prog Ser 222:187-196

Submitted: August 2, 2013; Accepted: January 27, 2014 Proofs received from author(s): April 15, 2014 